\title{
Multiple Realities, Multiple Representations, Multiple Selves: Re-Conceptualizing Authenticity in Designing Language Tasks as Deictic Practice
}

\author{
Razieh Rabbani Yekta
}

Department of Linguistics and Foreign Languages, Payam Noor University, PO Box: 19395-3697

Email: r_ryekta@yahoo.com, Iran

\section{Doi:10.5901/mjss.2015.v6n1s1p653}

\begin{abstract}
In this article, author considered the potentialities of deictic expressions in making intersubjectivity possible and also spiral of indexicality and reflexivity with the latter as a link between retention and protention ( the intentional act directed to the future) or analepsis (the evoking of the past in the present.) and prolepsis (evoking the future in the present) which are different modes of consciousness or Vygotsky's self and act as a way to raise expectations, suspense and capture attention. By this, author, through the correspondence between these potentialities inherent in deictic expressions, proposes the construction of deictic field as a context or ground of ecological validity for designing authentic learning task and environment which can weave the cognitive flexibility of the learners in developing multiple representations, multiple selves, and multiple realities.
\end{abstract}

Keywords: Authenticity Paradox; Deictic field; Ecological Research; Situated Cognition

\section{Introduction}

In recent years, the notion of authenticity has been redefined to match the current educational movements. In constructivism and its psychological counterpart, situated cognition, for example, authenticity has been defined as reality (Petraglia, 1998). In this sense, authentic activities are those that have real value to the learner and are of interest or use to the students' construction of their realities (Morgan \& Dennehy, 2004). But the thing that almost all the educational and psychological approaches agree with is that reality is not something purported; reality is not the real worldedness of a learning environment, technique or task; reality is something personal, the thing that is constructed through individual activities and perceptions and no educator can claim that something s/he offers students would be authentic (Petraglia, 1998; Coupland, 2003; Gill, 2007).

From another perspective, authenticity has been conflated with transferability of learning to everyday tasks. Here Petraglia, in what he called "authenticity paradox", argues against such a conception by emphasizing the fact that the differences in the mental representations of tasks in the learning and target situations have almost always been ignored (1998). Representation is "re-experiencing the situation in the imagination" which is based on the "affordances (attributes of the supporting features) and the constraints (the structure imposed by the setting [that] may facilitate task progress)" (Kennewell, et al., 2000; Kennewell, 2001; Bossard et al., 2008). According to Kennewell, for the learning tasks and situations to be authentic, both affordances and the constraints embodied in those settings should engage the learners in the multiple representations which are inherent in the human interactions with the environment.

But, in general, to establish a relationship of affordance with something (a physical, social or symbolic entity) we have to see/hear (sense, in general) that thing in relation to ourselves (van Lier, 2000). In his sociocultural theory, Vygotsky (1989) pointed to the notion of self as identical to consciousness which is shaped by and continuously enacted in sociocultural interaction and activity. In this sense, the experience is authentic when it can be connected with the real selves. Or in Sartre's word, "authenticity is not given, it has to be earned" (1957: 246).

In phenomenology, however, the human's subjectivity or self has something associated with it in what is described as the stream of consciousness - the continuous and contiguous flow of sensations, impressions, images, memories and thoughts-experienced by each person, at all levels of consciousness. Schutz (1982 [1924-28]; 1967 [1932]) defines this term from his phenomenological stance as the link between three different temporal domains of human cognition comprising retention or analepsis (evoking the past in the present), presentation, and protention or prolepsis (evoking the future in the present) (Husserl, 1997 [1948]). Accordingly, every experience is temporally organized with a synthesis of a given moment with its retentional and protentional extensions; and in this way, every process of meaning assignment is a process of reflexivity over the whole spectrum of experience by going forward or backward in awareness. Here, so many 
different terms we have under different approaches, that is, consciousness, self, individuality, subjectivity, experience of life, is, in fact, a continuum which, while coherent and united over time, doesn't have any unity at a time (Zahavi, 2011).

So the main question is how are we to conceive of a "continuum" across multiple timescales, multiple selves and multiple realities? What provides the continuity of our engagement with the world? How is knowledge acquired in one situation or activity transferable to another (Kirschner and Whitson 1998)?

In this article, author considered the potentialities of deictic expressions in making intersubjectivity possible (Kramsch, 2002) and also spiral of indexicality and reflexivity (Pfohl, 1985: 294) with the latter as a link between retention and protention ( the intentional act directed to the future) or analepsis (the evoking of the past in the present.) and prolepsis (evoking the future in the present ) which are different modes of consciousness (Husserl, 1997) or Vygotsky's self or role and act as a way to raise expectations, suspense and capture attention. By this, author, through the correspondence between these potentialities inherent in deictic expressions, proposes the construction of deictic field as a context or ground of ecological validity for designing authentic learning task and environment which can weave the cognitive flexibility of our learners in developing multiple representations, multiple selves, and multiple realities.

\section{Multiplicity-Friendly Learning Theories}

In the context of learning, in general, and language learning, in particular, the notion of multiplicity and unfixed context have been of concern in the studies (Kramsch, 2002; Leather \& van Dam, 2003; van Lier, 2000, 2002) that focus on the learner's active role in configuring a "semiotic budget" from the learning situations. In these studies which are based on ecological perspectives (Bateson, 2000; Gibson, 1979), human learning is an integrated entity involving cognitive, social, and environmental elements and learners' role is to engage diachronically and synchronically with the contextual elements of a specific setting.

Other researchers (Bakhtin, 1981; Lantolf, 2000a, 2000b; Vygotsky, 1978; Wertsch, 1991) argue that such a perspective to learning entails a kind of situatedness where learning is a tool-mediated social activity that occurs through social interactions at a specific time and place. These tools are the very cultural semiotic artfacts which mediate individuals' perceptual and conceptual boundaries, interests, worldviews and patterns of thought. As Van Lier (2000, 2002) mentioned, it is these semiotic budgets that help learners handle multiplicity in the environment.

Another learning theory which provides ecological grounds for transferability of learning in view of multiplicity is cognitive flexibility theory (Spiro \& Jehng, 1990, p. 165). Cognitive flexibility is "the ability to spontaneously restructure one's knowledge, in many ways, in adaptive response to radically changing situational demands". This is a function of both the way knowledge is represented (e.g., along multiple rather single conceptual dimensions) and the processes that operate on those mental representations (e.g., processes of schema assembly rather than intact schema retrieval)."

According to this theory, for the learner to be cognitively flexible, information should be presented from multiple perspectives and opportunities should be given to the learner to revisit a conceptual landscape from different directions and develop their own representations of information in order to master the complexity and fullness of a domain.

\section{Indexicals: A Semiotic Budget In Learning Environment}

In language learning context, one of the features of the linguistic input which increases the cognitive capacities of the learners to see and interpret a concept from different perspectives is indexicality or token-reflexivity. According to the principle of indexicality, the interpretation of a deictic expression is bound by the social and material context of the linguistic occurrence. As mentioned by Perry (2001), pure or essential indexicals ('I', 'here', 'now') are those that vary their reference purely as a function of point of view. They are playing the quasi-executive role (Corrazza, 2004). Their content which is in part supplied reflexively by the "inner awareness" is fixed by the context (the agent, location and / or time of the utterance or thought).

On the other hand, deixis is a semiotic code whose "design features" make it maximally flexible for use across fields: the relative absence of descriptive information in deictics, their near ubiquity in practice, and their relation to participants frameworks makes them an excellent resource through which to articulate the frame of reference with other social fields. So, by the spiral of indexicality and reflexivity, on the one hand, and deixis ability to embed values from other fields, on the other hand, the problem of criss-crossing multiplicities of time, selves and realities has got an answer.

\section{Mapping Multiplicity In Designing Language Learning Tasks}

In 1988 Ulric Neisser published a paper proposing five different kinds of self or self knowledge: ecological, interpersonal, 
extended, private, and conceptual. The first two can be seen together as the perceived self (Neisser, 1993), that is they are derived from perceiving the physical and the social world or from co-perceiving oneself simultaneously. The other three do not rely on perception but "on taking oneself as the object of thought". Therefore, we might group them together as the reflected self. The extended self draws on personal memories and builds anticipation; the private self is one's own individuality, and uniqueness; and the conceptual self draws on all theories beliefs and assumptions. In which the person is embedded, and includes social roles and identities. As for placing language-learning demands/tasks in the context of Neisser's five kinds of self-knowledge, Van Lier (2004, p. 118) proposed a type of protocurriculum for language learning that has been displayed in the following table:

Table 1. van Lier's protocurriculum based on Neisser's five kinds of self

\begin{tabular}{|c|c|}
\hline $\begin{array}{l}\text { 1. ecological } \\
\text { the physical environment }\end{array}$ & $\begin{array}{l}\text { Time and space. Deixis. The body. Speech acts. Peirce Indexical signs. } \\
\text { Demonstratives. Pronouns. Prepositions. Names. Categorization. }\end{array}$ \\
\hline $\begin{array}{l}\text { 2. interpersonal } \\
\text { emotional rapport and communication } \\
\text { 3. extended } \\
\text { personal memories and } \\
\text { expectations, my way of doing things }\end{array}$ & $\begin{array}{l}\text { Mutuality, reciprocity, intersubjectivity. Rapport. Turn taking. Rhythm, intonation. } \\
\text { Conversation. Formality, distance, intimacy. Later: social/societal expectations. } \\
\text { Memories, remembering. Story telling. Diaries. Looking for learning opportunities. } \\
\text { Strategies, initiative. }\end{array}$ \\
\hline $\begin{array}{l}\text { 4. private } \\
\text { personal uniqueness, separateness, } \\
\text { differences from everybody else }\end{array}$ & $\begin{array}{l}\text { Inner and private speech. Self knowledge (Gardner's Interpersonal intelligence). } \\
\text { Learning style. Self-presentation. }\end{array}$ \\
\hline $\begin{array}{l}\text { 5. conceptual } \\
\text { identity, roles and status, my 'theory of } \\
\text { me', my beliefs about myself }\end{array}$ & My expectations, investment, motivation. Notions of power, control. Discursive self. \\
\hline
\end{tabular}

As it is pointed out throughout the present paper, in addition to the first type of self knowledge, we can trace the potentiality of indexicality in all of these selves by using different tools in language learning situations which bring about different degrees of self detachment. Friedberg (2006), for example, said:

The screens of cinema, television, and computers open 'virtual windows' that ventilate the static materialities and temporalities of their viewers. A'windowed' multiplicity of perspectives implies new laws of 'presence'-not only here and there, but also then and now — a multiple view—sometimes enhanced, sometimes diminished-out the window ( $p .4-5)$.

In deictic shift theory, also, storytelling and narrative have been introduced as an authentic activity when the reader creates a mental model of the story world and then projects, or shifts, her deictic center into that model (Bennett, 2005). That is, in the process of reading, the reader responds to the textual cues provided by the author (who has likewise taken up one or more perspectives within the text in the process of creating it) to construct a deictic coordinate system in the world of the narrative. The reader then continues to reconstruct and reorient the deictic center, as cued by the text, during the course of the narrative.

As to the development of private and conceptual self, recent technological advances in storytelling provide some possibility for making this tool more flexible in developing learner's self knowledge or self awareness; indexical and environmental storytelling in the game space, for example, offer a series of strategies that use environmental design to help the player form the narrative script of a game (Fernández-Vara, 2011). Through this possibility, player can build her/his own interpretations of the world in the game and assign a unique meaning to the world s/he encounters (Jongeneel, 2013).

Sound Motion Pictures (SMP) are also another tool which can put the dynamic nature of indexicals at the service of language learning. Chen and Oller ( 2005) argue that teachers, by the correct application of SMP can generate and control three different types of indexical relations: (1) objective indexes emanating from material bodily objects to observers, (2) subjective indexes projected from observers onto bodily objects, and (3) symbolic indexes marking linguistic associations between the surface forms of the target language and their referents as well as relations between all of these.

These are just a few cases which show the probable potentiality of deictic expressions as lenses through which it is possible to see from multiple perspectives. But to know more about the affordances or the "semiotic budget" that these components offer, one should conduct a research which would be contextualized or situative, have spatial and temporal dimensions and be ecologically and phenomenologically valid, particularly in terms of a correspondence between researchers' and participants' situation definition (Van Lier, 2002). A conglomerate of these features can be found in action research (or other intervention studies), case studies, ethnographies, and various forms of collaborative research 
which all are classified under the term ecological research (Bronfenbrenner, 1993).

\section{Conclusion}

Regarding the definition of authentic learning by Petragria (ibid) and the requirement of the authentic tasks for making multiple representation and cognitive flexibility possible in language learners, author in this article proposed that the five selves or five kinds of self knowledge inherent in deictic expressions can weave the learners' cognitive flexibility. In other words, author suggested that the use of deictic expressions in classroom language practice can enhance the ecological validity of instruction.

\section{References}

Bakhtin, Mikhail Mikhailovich. (1981). Excerpts from discourse in the novel. In M. Holquist (Ed.), The dialogic imagination: Four essays by M. M. Bakhtin. Austin, TX: University of Texas Press.

Bateson, G. (2000). Steps to an ecology of mind: Collected essays in anthropology, psychiatry, evolution, and epistemology. Chicago, IL: University Of Chicago Press.

Bennett, A. (2005). Expanding deictic shift theory: person deixis in Chuck

Palahniuk's FIGHT CLUB. An Unpublished thesis submitted for the master's degree in the University of Kentucky, Lexington.

Bronfenbrenner, Urie. (1993). The ecology of cognitive development: Research models and fugitive findings. In Wozniak, R. H. \& Fischer, K. W. (Eds.), Development in context: Acting and thinking in specific environments (pp. 3- 44). Hillsdale, NJ: Erlbaum.

Chen, Lihan, \& Oller, John. (2005). High quality sound motion pictures in L2 curricula: Why and how they work. Canadian Modern Language Review, 62(2), 263-284.

Clandinin, D. J. \& Connelly, F. M. (1995). Teachers' Professional Knowledge Landscape. NewYork: Teachers College Press.

Corazza, E. (2004). Reflecting the mind: Indexicality and quasi-indexicality. Oxford: Oxford University Press.

Coupland, Nikolas. (2003). Sociolinguistics authenticities. Journal of Sociolinguistics, 7(3), 417-31.

Bossard,Cyril., Kermarrec, Gilles., Buche, Ce 'dric. \& Tisseau, Jacques. (2008). Transfer of learning in virtual environments: a new challenge? Virtual Reality, 12(3), 151-161.

Duranti, A., \& Goodwin, C. (1992). Rethinking context. New York: Cambridge University Press.

Fernández-Vara, Clara. (2011). Game Spaces Speak Volumes Indexical Storytelling. Unpublished. Retrieved August 05, 2013 from: http://www.academia.edu/1035378/Game_Spaces_Speak_Volumes_Indexical_storytelling

Friedberg, A. (2006). The Virtual Window: From Allberti to Microsoft, Cambridge, Mass.: The MIT Press

Gibson, J. J. (1979). An ecological approach to visual perception. Boston, MA: Houghton Mifflin.

Gill, Martin. (2007). Exclusive boundaries, contested claims: authenticity, language and ideology. Paper presented at the 40th Annual Conference of the British Association for Applied Linguistics, University of Edinburgh, September 6th.

Husserl, E. (1997 [1948]). Experience and Judgment. Evanston, IL: Northwestern University Press.

Jongeneel, Jethero. (2013). Environmental Storytelling in a New and Unexplored World, Masters Thesis Level Design, Glasgow Caledonian University, retrieved from: http://www.johnsto.co.uk/design/

Kennewell, Steve. (2001). Using affordances and constraints to evaluate the use of ICT in teaching and learning, Journal of IT and Teacher Education, 10, 101-116.

Kennewell, S., Parkinson, J., \& Tanner,H. (2000). Developing the ICT Capable School. Routledge Falmer, London.

Kirshner, David., \& Whitson, James. A. (1998). Obstacles to understanding cognition as situated. Educational Researcher, 27(8), 22-28.

Kramsch, C. (Ed.). (2002). Language acquisition and language socialization:Ecological perspectives. London: Continuum.

Lantolf, J. (2000a). Introducing sociocultural theory. In J. Lantolf (Ed.), Sociocultural theory and second language learning. New York, NY: Oxford University Press.

Lantolf, James. (2000b). Second language learning as a mediated process. Language Learning, 33(2), 79-96.

Leather, J., \& vanDam, J. (Eds.). (2003). Ecology of language acquisition.

Dordrecht, The Netherlands: Kluwer Academic Publishers.

Morgan, Sandra. \& Dennehy, Robert. F. (2004). Using stories to reframe the social construction of reality: a trio of activities Journal of Management Education, 28.

Neisser, U. (ed). (1993). The Perceived Self: Ecological and Interpersonal Sources of Self-Knowledge. Cambridge: Cambridge University Press.

Perry, J. (2001). Reference and reflexivity. Stanford: CSLI Publications.

Petraglia, J. (1998). Reality By Design: The Rhetoric and Technology of Authenticity in Education, Manwah, NJ: Lawrence Erlbaum.

Pfohl, S. (1985). Images of Deviance and Social Control: A Sociological History. New York: McGraw-Hill.

Sartre, J.P. (1957). Being and nothingness. London. Methuen.

Schutz, A. (1982 [1924-28]). Life Forms and Meaning Structure. London: Routledge \& Kegan Paul.

Schutz, A. (1967 [1932]). The Phenomenology of the Social World. Evanston, IL:Northwestern University Press.

Spiro, R., Jehng, J. (1990). Cognitive flexibility and hypertext: Theory and

technology for the nonlinear and multidimensional traversal of complex subject matter. In Nix, D., Spiro, R. (Eds.), Cognition, education 
and multimedia: Exploring ideas in high technology (pp. 163-205). Hillsdale, NJ: Lawrence Erlbaum Associates, Inc.

van Lier, L. (2000). From input to affordances: Social interactive learning from an ecological perspective. In J. Lantolf (Ed.), Sociocultural theory and second language learning (pp. 133-153). New York: Oxford University Press.

van Lier, L. (2002). Ecology and Semiotics of Language Learning: A Sociocultural Perspective. Norwell, MA: Kluwer Academic Publishers.

Vygotsky, L.S. (1986). Thought and Language. Cambridge, MA: MIT Press.

Zahavi, D. (2011). Unity of Consciousness and the Problem of Self . In S. Gallagher (ed.): Oxford Handbook of the Self. Oxford: Oxford University Press, 314- 333. 